THE PEACE-MAKING MOTHER:

\title{
READING JOHN 2:1-12 IN THE CONTEXT OF RWANDAN POST-GENOCIDE WOMEN
}

\author{
Rose Mukansengimana Nyirimana ${ }^{1}$ and Jonathan A Draper ${ }^{2}$ \\ School of Religion Philosophy and Classics \\ University of KwaZulu-Natal
}

\begin{abstract}
In John's narrative of the Wedding at Cana, Jesus' mother displays key qualities which contribute to the resolution of a crisis. Her awareness of the problematic situation before anybody else, her belief that a solution could be found, her initiative in taking the first step toward finding a solution, and her influence beyond blood ties extending to the servants, all contribute to the accomplishment of the sign at Cana. The miracle that resolved the crisis was executed by the powerful Jesus but at the instigation of his wise mother who received little credit. The hosts were saved from shame and embarrassment, the disciples' faith strengthened and Jesus glorified. The atmosphere of peace and joy was maintained at the wedding because of Jesus' mother's initiative. Her attitude serves as an inspiration for women in today's society, in the African context and specifically in Rwandan post-genocide context. Jesus' mother is a mirror for Rwandan women who are challenged to contribute to building peace in their context. This essay adopts an African Inculturation hermeneutical framework inspired by the work of the late Justin Ukpong, which makes the context of the African reader the subject of interpretation. The narrative of John 2:1-12 is read from the perspective of Rwandan women in peace-making roles in situations of conflict. We begin with a brief description of the African Inculturation hermeneutical approach guiding the discussion.
\end{abstract}

Key Words: Conflict; Peace; Peacemaking; Reconciliation; Genocide; Blood Ties

\section{Introduction}

The late Justin Ukpong developed his African Inculturation hermeneutical approach as a response to the domination of interpretations of the Bible based on Western historical critical readings which were experienced as alien and alienating to Africans in the aftermath of colonial domination. He emphasizes the African context and the African reader in dialogue with the text. His approach seeks to interpret the biblical text from the sociocultural perspective of African people, including both their religious and secular culture and their social and historical experiences (Ukpong 1995:190). In other words, the text is read

Rose Nyirimana Mukansengimana $(\mathrm{PhD})$ is a Rwandan. She is New Testament scholar at the School of Religion, Philosophy and Classics at the University of KwaZulu-Natal. Her areas of interest are centred in contextual exegesis focusing on the plight and role of Women and Peace-making in the Gospels.

2 Jonathan A Draper (PhD) is Professor of New Testament Studies in the School of Religion, Philosophy and Classics at the University of KwaZulu-Natal. His research interests are centred in early Jewish and Christian literature, specialising in the Didache, the Gospel of John and early receptions of the Bible in Africa. 
with African eyes within a given African context, which means that the reader/interpreter approaches the text with a critical awareness about his/her contemporary context and allows the text to evoke in him/her appropriate responses and commitments arising from the context (Nyririmana 2010:30). The African Inculturation hermeneutical approach which is adopted in this article, therefore stresses the fact that the context of the reader informs the interpretation since, "There are no neutral readings of the text. Our context prompts us in the questions we bring to the text and decides what counts as answers. The context in question is not simply our faith context, but also our cultural, socio-economic and our class interests" (Draper 2001:156-7). The 'ideo-theological choices', as Gerald West (2009) describes them, of the reader/interpreter then bring the text and its context into dialogue with the concerns of the reader in her/his context, leading to the possibility of a changed praxis. The present study represents an inculturation hermeneutical reading of John 2:1-12 from the perspective of the Rwandan context of conflict. Situations of conflict in Africa in general and in Rwanda in particular guide the reading of the text. Moreover, the particular experience and contribution of Rwandan women in making peace or failing to do so during the Rwandan genocide of 1994 informs the questions which are asked and the reading which emerges. While the readers seek to listen to the voice and rhetoric of the text, this is not a disinterested reading. Rather, the Johannine narrative will be read as an 'inter-text' with the Rwandan narrative of the tragedy of the genocide. The moment of listening to John will be placed alongside and intertwined with the questions raised by a Rwandan woman's reading of her own situation.

The story reported in John 2:1-12 is an account of Jesus' first sign. The context of this sign is a crisis generated by the shortage of wine, threatening to shame a host who has guests to entertain. In this crisis Jesus' mother is characterized as a hero. Although she is not the one resolving the crisis, she is instrumental in finding the solution so that the positive ending of the story is due largely to her involvement.

The Cana wedding event is read from the perspective of conflict resolution, focusing on the role of women in preventing or resolving conflict in their communities. The article aims at discovering the strategies behind the characterization of Jesus' mother in solving a crisis at the Cana wedding, and how her strategy can become an inspiration for women to prevent crises in their communities or to resolve crises when they threaten to get out of hand. This article reads the narrative as an inspiration to women in Africa in general and to Rwandan women in particular.

Narrative criticism serves here as a reading methodology guided by African realities and assists in understanding the message of the biblical text from the perspective of the worldview and context of Rwandan women. The analysis is guided by some of the literary questions suggested by Malbon (2000:17) which point to what the text may mean, and how the various literary patterns enable the text to communicate its meaning rhetorically to the hearers and readers of the narrative. The questions are summed up in what Malbon has called the five 'W's that describe the elements of narrative: who (characters), where and when (settings), what and why (plot). The analysis of the text begins with the questions 'where' and 'when' which introduce the geographical and time setting of the event - the other questions follow as the analysis unfolds. But before engaging in the analysis of the text, it is necessary to examine the motivation for taking the subject of women and conflict as the basis for reading the narrative of the Wedding at Cana of Galilee in John. 


\section{Women and Conflict Management}

In many cultures, and certainly in Rwandan culture, women are culturally considered and trained to be peace-makers while males are trained for warfare and to be aggressive, but that is a social construct. Diana Francis observes that:

People laugh when little boys fight and say, 'boys will be boys', recreating on a daily basis the notion that to be properly male is to be aggressive. Fighting is seen as an aberration in little girls. They, by contrast, are expected to be gentle and caring... It is inescapable that when we think of violence in general we think - first and foremost - of men, or of men-in-the making. When we think of wars, and images of war, the same is true. Young men are prepared by the society for war (Francis 2004:66-67).

Indeed some cultures and traditions consider women more caring and prone to unitybuilding. That assumption is often expressed in their adages and proverbs. This is exemplified in Rwandan culture where the woman is assumed to have attributes that make her an instrument of social cohesion. The saying Umugore ni gahuza miryango, meaning 'a woman serves as a bridge between families and tribes' expresses Rwandans' belief in the idea that a woman is a mediator or a bridge-builder between extended families, clans, tribes and neighbours. The tradition then assumes that women are endowed with the capacity to restore broken relationships and create long-lasting friendships with the members of different groups. In terms of conflict resolution, the saying also expresses the role of the mother in maintaining stability and peace in her own family.

John Paul Lederach (1995) observes that in the Mexican tradition there is no specific vocabulary that defines the term 'conflict'. They use the word desmadre which translates as 'disorder' or 'chaos'. The term, however, literally means to be 'without a mother'. Lederach focuses the reader's attention on the fact that the metaphor of desmadre as conflict does not refer to the absence of the father, but to the situation of the more total and devastating disintegration that emerges without the presence of a mother. Lederach believes therefore that, practically, this provides a clear understanding of the central role of women in the resolution of family conflicts in the Latin American context. According to Lederach this term highlights two major things about women: their culturally determined inclination for resolving conflicts and their consequent key conciliatory role in maintaining harmony among people (Lederach 1995:75-76).

The Mexican tradition matches a similar tradition in Rwanda which views women as the promoters of the well-being of the family by the adage: ukurusha umugore akurusha n'urugo, meaning 'The one who has a better wife has a better home'. This cultural tendency is displayed in all circumstances, even in time of conflict and crises. However, such cultural norms set by patriarchal societies do not allow women to display such qualities at a wider level, as they are only allowed to play such important roles in the home. This article then suggests to Rwandan women and those in solidarity with them a reading of the Cana wedding in the light of conflict prevention and resolution in the society, using the example of Jesus' mother. The depiction of the role of Jesus' mother in a social role wider than that of a woman's own home suggests that prevention is better than cure, especially when read against the background of the Rwandan experience. 


\section{The Crisis at Cana Wedding John 2:1-12}

\section{Setting of the Wedding}

Vlassenroot argues that conflict is understood better in its social setting as it helps to know its roots and understand why and how people turn to it (Vlassenroot 2006:49). The wedding event took place at Cana in Galilee. In the New Testament, Cana is mentioned only in the Fourth Gospel where two miracles are reported to have occurred (John 2:1-12 and 4:46-50). Cana is identified as a place where the glory of the Son of man took shape in the miracle of the abundance of wine (Ridderbos 1997:97). However, scholars do not agree about the exact location of Cana where the wedding took place. Four villages in Galilee are candidates for the biblical Cana: Kafr Kanna, Kenet-Jalil, Ain Kana and Qana Lebanone (Brown 1984:98). While the scope of this article does not allow much discussion on the details of the true Cana among the suggested four regions, we begin instead with HowardBrook's argument that Jesus begins his activity not in the headquarters of the Law, nor in the centre of the religious world of Israel, but on the obscure margins, hidden, quiet, yet invited (Howard-Brook 1994:78). Such a location, not in a big city, but in a small town in Galilee in a rural area, explains the strong emphasis on the cultural norms at the wedding event. The failure to observe traditional cultural rules would cause conflict at that wedding, particularly in the traditional rural setting John describes. This situation resonates with the experience of Rwandan women in a society which is mostly rural and where cultural traditions remain prescriptive in situations such as weddings.

In terms of the 'when' of the narrative, the narrator does not provide clear information. The story opens with an indication that the wedding took place on the third day (v1). The

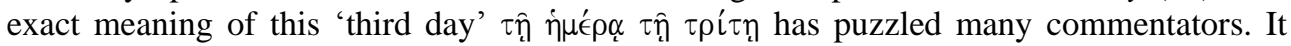
seems reasonable to understand that the narrator situated the wedding on the third day of or after something which is not stated clearly. ${ }^{3}$ The 'third day' may be taken simply as connecting the wedding to prior events which initiate Jesus' public role and his emergence from the sphere of home and family. However, the resonances of the term 'third day' with the resurrection of Jesus will be allowed to infuse the story of conflict with the light of hope that conflict may be transcended. This is particularly appropriate in view of Jesus' insistence to his mother that 'my hour is not yet' which, as we will see, seems to refer forward to his own death on the cross.

\section{Jesus and his Mother at Cana (John 2:1-12)}

Few details are provided about the wedding. The custom in first century Jewish culture was that wedding celebrations normally lasted for seven days (Keener 2003:499). The narrator seems less interested in what happened during the other days; he is interested rather in an event that occurred on one particular day of the wedding. He is interested in only a few characters at the wedding; he identifies only the mother of Jesus, Jesus, the disciples, the

\footnotetext{
One plausible way of reading the text is by counting 'the third day' from the last event narrated namely, Jesus' encounter with Nathanael (1:43-51). Suggit concurs with the idea by asserting that "the pericope has been preceded by the story of the coming of Nathanael to Jesus, which it linked especially by the use of the phrase "the third day"' (Suggit 1993:37). Various theological interpretations have been suggested for 'the third day' in this passage. For instance Ridderbos has contended that there is no sufficient ground to ascribe to "the third day' any other meaning than that it serves to establish a direct historical and material connection between the story that follows and what takes place two days earlier between Jesus and Nathanael (Ridderbos 1997:103). However, for others the 'third day' is connected to the day Jesus rose again from the dead.
} 
servants and the master of ceremonies, whose roles also differ. The main characters who play a core role for the purpose of this article are Jesus and his mother.

\section{Jesus and his Mother: John 2:1-12}

After his mother, Jesus is the next character to be introduced together with his disciples (verse 2). Jesus is not invited with his mother; he is associated with his disciples rather than with his parent. But the repeated reference to Jesus' mother in this account reminds the reader that, though some believers in John's time had started hinting at Jesus' divine origin (1:29-51) - which had already been confirmed for the reader in the Prologue in 1:1-18 Jesus still had an earthly family. However, the silence on the whereabouts of the earthly father when there is an earthly mother through whom the Word 'became flesh' raises questions in the mind of some readers. The narrator provides accounts of Jesus with his mother during Jesus' ministry without any mention of his father's presence. The lack of information about an active father in Jesus' life in the Fourth Gospel has led some scholars to assume the possibility of Jesus' fatherlessness. Reinhartz and Lee argue that while the Fourth Gospel refers to God as Jesus' Father approximately one hundred and nineteen times, it refers to his earthly father only twice (Reinhartz 1999:1; Lee 2002:112). Van Aarde argues that Joseph was not part of Jesus' life because he was either dead or had abandoned the family (Van Aarde 2001:112-7). ${ }^{4}$ In the absence of an active father, Jesus' relationship with his mother receives a special significance twice in the narrative - here and at the foot of the cross. From the perspective of this Rwandan reading of John's narrative, the absence of a father is particularly poignant in a context where so many have lost family members and particularly fathers (so significant in a patriarchal society) either to genocide or to exile. It suggests even more urgency for women to find an active role in building a new conflict-free Rwanda. Both of John's narratives about the mother of Jesus occur in the public sphere beyond the home. However, at Cana, his first reaction to his mother's request creates further questions.

\section{The Mother of Jesus}

The mother of Jesus is introduced in a way that makes her a principal actor in the event. She is the first person to be mentioned at the beginning of the story and "this is a significant detail since the introductory verses could have been written in any of a hundred different ways" (Brodie 1993:174). It is unusual to introduce such an event and start with the presence of a woman, especially in that society where women were marginalized and neglected. But the mention of her presence at the venue as the first detail provided about the wedding is an indication that she is likely to be at the centre of the story - an agent rather than a passive figure in the rhetoric of the narrative.

It should be observed that the mother of Jesus is not named anywhere in the Gospel of John. Much has been speculated about the omission of her name. O'Day's observation reported by Nortje-Meyer's (2009) article suggests that the omission of women's names may be seen as an indication that women were marginalized in the Church's early years. But for Witherington and Malina the phrase 'the mother of Jesus' is almost a technical term

4 The discussion of the issue of Jesus' fatherlessness is beyond the scope of the present study. Suffice it to say here that the silence about Jesus' father in the story under examination gives even more room to the mother, the only parent present, to be close to the son, so as to have an opportunity to enjoy his undivided attention and eventually to exert upon him an unaltered influence. 
of John. To them this phrase is an honourable title for a woman who has borne a son; however, it implies no veneration of Mary's person, but focuses on her role (Witherington 1990:89; Malina 1998:66). Nortje-Meyer notes that “Jesus' mother's identity is always established by her relationship to Jesus and therefore her maternal role is her defining characteristic" (Nortje-Meyer 2009:126-131). This explanation is validated by a similar practice in Rwanda where mothers are called by the names of their children - their eldest sons preferably. Here she has to overcome this subordination of her status to the role of mother to become the hero in the narrative for the resolution of a crisis at the Cana wedding.

\section{Jesus' Mother's Intervention in Solving the Crisis}

Jesus' mother's intervention is reported in two scenes (2:1-4 and 2:5-12). In the first scene she reports the crisis to her son who declares his unwillingness to be involved. In the second scene the mother's act of involving the servants foretells the success of her influence on him in solving the crisis.

\section{The Mother Attempts to Influence the Son (Verse 3)}

From the outset of his account, the narrator reports the crisis that consists of a shortage of wine at the wedding (verse 3). In Jewish thought, wine is a symbol of joy and celebration as Köstenberger observes: "There is no rejoicing save with wine (b. Pesah. 109 a). At a cultural level, running out of wine was considered to be a major social faux pas, since the host was responsible for providing the wedding guests with wine for seven days. There may even have been legal obligations" (Köstenberger 2004:93). The fact that the family hosting the wedding has run out of wine threatens a serious loss of honour. Friends, especially those from the inner group of wedding celebrants, usually sent gifts, such as wine, ahead of time to be available for the wedding celebration. Lack of wine thus implies lack of friends (Malina 1998:66), or poverty, both of which were damaging to the reputation of the host. The failure to solve the original crisis would have created a further crisis in the new home as the groom had failed to take good care of his guests, including the family of the bride. Keener evaluates the possible implications of such a crisis to the reputation of the groom in the following words:

What is more certain [is that] the groom was facing a potential social stigma that could make him the talk of his guests for years to come. Wine was important to any properly hosted public celebration, and wedding guests sometimes drank late into the night... Nevertheless, in Jewish culture, it was customary to have food left over at weddings, that is, never come close to running out, and proper hospitality toward wedding guests was so crucial that $t$. B. Qam. 7:8 includes among thieves 'He who presses his fellow to come as a high guest but does not intend to receive him properly' (Keener 2003:503).

The mother of Jesus is credited with realizing the gravity of the situation and taking the crucial initiative to relieve their embarrassment. As Keener observes, women sometimes have access to privileged information not spoken in the company of men (Keener 2003:503). Jesus' mother did not sit passively with the information. She directed the

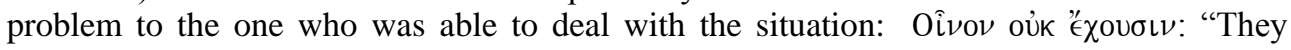
have no wine" (verse 3). 


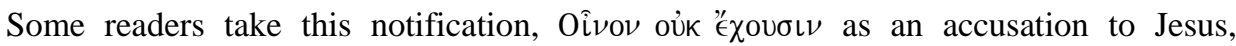
arguing that he brought his disciples with inadequate gifts to defray the expenses of the wedding; so that Jesus and his followers are partly at fault for the wine running out (Keener 2003:502, Whitacre 1999:78). Whether or not this observation has a solid basis in Jewish culture, it could not apply in traditional Rwandan culture where, though gifts from neighbours and friends are surely expected in ceremonies of this kind, the host remains solely responsible for providing enough drinks for the guests, and the shortage of drinks cannot be blamed on anyone else. However, this article does not consider Jesus' mother as making an accusation, rather the statement is viewed as an implied request to him. She acts on the presumption that Jesus will grant her request. This is comparable to reports of the audacious faith of other women and men in the Hebrew Bible ${ }^{5}$ and in the Gospel tradition. ${ }^{6}$ Her directions to the servants in verse 5 shows that she has unlimited confidence in Jesus' capacity to provide that help.

Kruse argues that the mother was confident that Jesus would listen to her simply because she was his mother (Kruse 2003:92). Kruse's argument evokes the kind of mother's influence stemming from a blood relationship and/or parental authority and the resulting son's respect such as has been often seen in past and contemporary political leadership. If the mother of Jesus had been successful in this approach it would only have confirmed her subordinate role in patriarchal culture, a kind of defeat in victory. In Rwandan history, this kind of influence allowed queen mothers and other close female relatives to wield considerable influence over the kings to the extent of sometime dictating to the monarchs. In first century Jewish culture, the same kind of role is reflected from the mother of James and John in Matthew's redaction (Matthew 20:20-28). If Jesus had succumbed to his kind of blood and kinship influence, it is likely that what emerged would have been a dynasty rather than a message of liberation which transcended national, racial and (ultimately) gender barriers. In contemporary democracies, the basis of influence has gone beyond blood relation to include what is called in Rwanda ikimenyane (bias based on acquaintances or connections). The influence of family and friends and their meddling in leadership and decision-making has produced nepotism and patrimonialism in various societies in Africa and beyond, and undermined the ability of women to stand against the bloodletting between Hutu and Tutsi people which swept through Rwanda in 1994. So, Jesus' response to his mother's attempt to exercise this kind of influence is of great interest to Rwandan women reflecting on the aftermath of the genocide.

Jesus' mother may have capitalized on the possible effect of her influence as a mother over her son. Being Jesus' mother qualified her culturally to enjoy a share in his power, honour and prestige. Power, in the ancient world, was not the rule of one individual over other individuals, but a family exercising control over other families (Hanson 1998:81). A mother of the patron could hope to enjoy benefits ranging from considerable power similar to that wielded by queen mothers in traditional Rwanda and elsewhere, to material privileges open to kinspeople of the patron as it is observed in contemporary patrimonial regimes. At the Cana wedding, the narrator does not stress such ambition on the side of Jesus' mother; nevertheless, she attempted to use her blood relationship to influence him to

Keener cites in comparison the cases of Jacob in Genesis 32:26-30; Moses in Exodus 33:12-34:39; the Shunammite woman in 2 Kings 4:14-28; Elisha in 2 Kings 2:2,4,6,9; and Elijah in 1 Kings 18:36-37, 41-46.

6 Here Keener refers to the case of the woman with an issue of blood in Mark 5:27-34; the Syro-Phoenician woman in Mark 7:24-30; the blind Bartimaeus in Mark 10:46-51; and the centurion in Mathew 8:7-13. 
provide for their needy friends. However, the tone of his answer to his mother's request indicates his intention to distance himself from such an exercise of special 'influence'.

\section{Jesus' Resistance to the Blood Relationship Influence (Verse 4)}

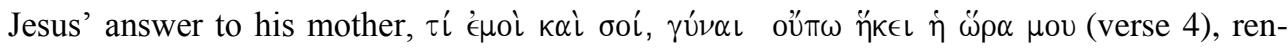
dered literally "what (is it) to me and to you, woman? My hour has not yet come", has

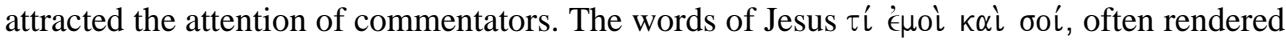
"what have I to do with you?" or "why do you involve me?" or "what does your concern have to do with me?" connote a sharp rejection of his mother's request. It indicates some sort of confrontation or rebuke (Kruse 2003:92). Bechtel reads in this statement an expression of lack of relationship, outright discord or hostility. In Bechtel's symbolic interpretation, the expression here means the breaking of Jesus' relationship with Judaism (Bechtel 1996:249), but this goes beyond the evidence of the text.

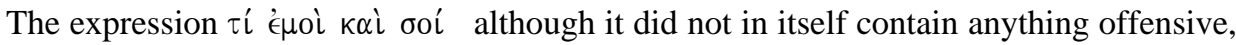
has the material intent of a sharp reprimand (Ridderbos 1997:105). In view of the prominent role assigned to honouring one's parent in Judaism (and indeed in ancient Mediterranean in general), Jesus is establishing a degree of distance between himself and his mother, as did the Jesus of the Synoptic tradition in Mark 3:31-35 and parallels (Keener 20:505). That distance is even apparent in the way he addresses her, with the vocative

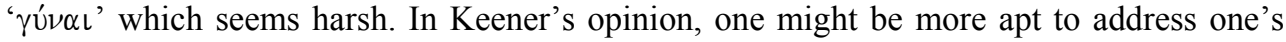
mother with a title such as ' $к u \rho i \alpha$ ', a respectful title for a woman of rank (Keener 2003:504). Ridderbos admits that in the social context of the time, the address 'woman' was in itself certainly not impolite. But as the address of a son to his mother it is not common and may seem distant and impersonal (Ridderbos 1997:105). This expression is just as inconceivable in African culture, especially in Rwanda; no child can call his /her mother mugore ('woman'). In the context of the present account, the narrator seems not to expect his reader to understand the address ' $\gamma u$ v $\alpha$ ' ' as Jesus' usual way of addressing his mother expressed in his apparent negative answer. Jesus is not favourable to the request, and the reason he gives is that his time has not yet come. The enigmatic words

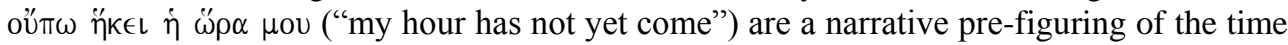
of Jesus' glorification, the moment of fulfilment of his purpose through his death and resurrection. ${ }^{7}$ From a Rwandan perspective, the reference to Jesus' hour reminds the reader strongly of the terror of violent and unjust death in the pursuit of power and the attempt to settle old and unresolved conflicts by force. They also point to the possibility of a new way of resolving such conflicts symbolized by Jesus' self-offering death and God's response in raising him from the dead - new life and hope arising out of death and despair.

Jesus' answer to his mother brings an end to the first scene on a worrying note in the plot. The hope of seeing the crisis resolved diminishes as it is jeopardized by Jesus' negative answer. But the next scene describes the persisting mother who does not give up; she acts like the widow and the judge in Luke 18:1-8, who, by 'persistently insisting' (Dube 2003), was granted justice. In the same way, Jesus' mother's persistence and faith stirred Jesus into action, not now on the basis of her kinship rights but on the basis of the justice of her appeal and her confidence and faith in her son's response.

Kruse (2003:92) and Whitacre (1999:79) argue that Jesus is referring to his death and the events that follow; they believe that Jesus' words are to be understood as done under the shadow of the cross, resurrection and ascension. 


\section{Successful Influence: Faith Versus Blood Relationship (verses 5-8)}

After her talk with her son, Jesus' mother turns to the servants. Her words to the servants, "Whatever he says to you, do it" (verse 5), reveals her persisting attitude and her faith that he will provide a solution. After Jesus' rebuke, she came to understand that faith constitutes a better basis of influence than kinship. With such a new understanding, she believed that the time would come when he would act in response to her act of faith. Hence, as Köstenberger (2004:95) argues, though Jesus' mother does not have authority over Jesus, she does express her faith in action.

The scene is dominated by Jesus' mother; the servants are passive characters who listen to instructions. Jesus' mother functions as a model of faith and determination, which is a prior component as well as the result of the sign that Jesus is to perform. She is portrayed not as holding or exercising power to resolve the crisis, but as an exercising agency by involving the one who can bring a solution. She proceeds by preparing the servants, whose obedience is necessary to achieve the solution. Her awareness of the problem, her persistence and refusal to be put off serve as a key to the solution of the crisis.

The narrator introduces other means needed for solution of the problem which is the

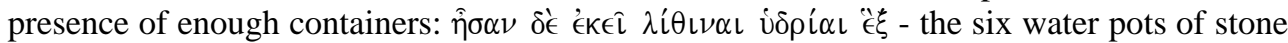

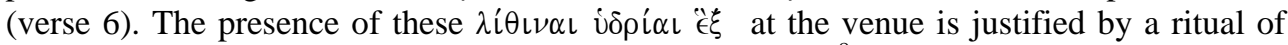
purification required in Judean traditions (Malina 1998:68). ${ }^{8}$ The specific reference to these Judean cultural artefacts for washing away impurity (and perhaps the guilt which goes with it) may represent a challenge to find solutions to communal problems within the specific cultural resources of communities. Cultural factors may aggravate conflicts, but they may present unexpected resources to resolve it. Reading from the perspective of Rwandan women, we may see this as a challenge to critique but also to explore the possibilities within Rwandan culture for conflict resolution.

In any case, after his sharp rejection of his mother's request, Jesus is apparently acting just as the mother had thought (verse 5). The implied narrator seems to indicate that Jesus wanted his mother to learn that her relationship to him as a disciple was more important than her relationship to him as mother. She needed to embrace a faith-relationship in order to reach the wider society beyond the family and kin. Hence, her influence does not stop with her son but it also extends to the servants. Mindful of her advice, the servants obey and fill the water pots to the brim. ${ }^{9}$ They even go further in obeying his instruction: to draw water out and take it to the master of the banquet (verse 8), where they may have anticipated ridicule from the wedding guests for bringing in water instead of wine. ${ }^{10}$ Their

8 Recent archaeological discoveries have confirmed the existence of such stone water jars in first century Galilee, manufactured in Jerusalem and hence 'Judean' as they are described here (see e.g.

http://dqhall59.com/israelphotosIV/stonewaterjars.htm accessed 25/06/2013).

$9 \quad$ Filling the water pots to the brim has been interpreted symbolically in reference to the gospel's depiction of Jesus as the one who is able to provide amply, spiritually (10:10) as well as materially, and the one who "gives the Spirit without measure" (Keener 2003:513). For the reader of this story, however, the magnitude of the miracle to follow is more straightforward (Kruse 2003:93). Filling the water pots to the brim may also prove the impossibility of deception or fraud (Köstenberger 2004:97).

10 While this is not stated, it constitutes a 'narrative gap' (Wolfgang Iser) which draws the hearer/reader into supplying such a link, as concisely summarised by David Alberson (2000) in his Stanford Presidential Lecture: "For Iser, the reader does not mine out an objective meaning hidden within the text. Rather, literature generates effects of meaning for the reader in a virtual space created between reader and text. Although reader and text assume similar conventions from reality, texts leave great portions unexplained to the reader, whether as gaps in the narrative or as structural limits of the text's representation of the world. This basic 
obedience showed implicit faith in Jesus' word (Kruse 2003:93). The mother had prepared them to do whatever the son would tell them as it was easier to see Jesus as just one of the many guests without providing explanations for the instructions which would not have made much sense to them. In obeying Jesus' mother, the servants contributed to saving their master, the host of the wedding feast, from what in Jewish culture would mean dishonour and a public humiliation.

\section{Crisis Averted: The Hosts are saved from Public Shame (Verses 9-10)}

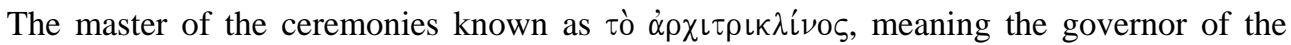
feast or, according to Keener, 'ruler of the table' (Keener 2003:514) is brought into the scene in the second part. The master of the banquet, who had not been aware that he was under threat of being confused and shamed, tastes the new wine and marvels at its abundance and superior quality (verse 10). He did not know where the wine came from, nor that it was water drawn from the well, albeit transformed by Jesus' action. It is on account of his unbiased ignorance that he addresses not Jesus, but the bridegroom as the person whose family was solely responsible for the wine supply and makes known his astonishment at the course of action that has been followed in saving the best wine till last (Ridderbos 1997:108). The crisis is over; Jesus finally responded favourably to the request of his mother not as a mother in a position of family influence but as a woman of faith exercising agency.

At last, the presence of the bridegroom is mentioned but without an active role to play. This is an indication that the story is not about the wedding, but about a crisis miraculously resolved by Jesus at the instigation of his mother as a woman of faith. But it is not only the host and his guests who benefited from Jesus mother's shrewdness, even Jesus had his own share. His glory was revealed both in his ability to change water to wine, and also in his grace in providing an abundance of quality wine, to spare the bridegroom shame and loss of face (Kruse 2003:93), which symbolically prefigures the fulfilment of 'his hour' through which those who believe in him receive not just life but life of a higher quality, life 'in its

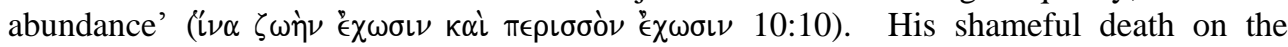
cross and his ultimate triumph through God's vindication, as mentioned in the narrative: his declaration, "The hour has come for the Son of Man to be glorified"' (12:23) is affirmed by the Father whom he invokes: 'Father, glorify your name'. Then a voice came from heaven, "I have glorified it, and I will glorify it again"' (12:28). As Feuillet argues, in the Cana event attention is not on the miraculous character of the change of water into wine but on the unique role prophetically assigned to Jesus in the history of salvation, and the subsequent manifestation of his divine glory (Feuillet 1986:365). However, for Rwandan women this also signals the possibility of life from death, the possibility of new beginnings. At the end of the narrative, the mother is mentioned as a member of the company of the disciples whose faith she has contributed to strengthening (verse 12). The mother of Jesus then is depicted as exercising her autonomy as a believer and participates in building up a new community of believers. "His disciples put their faith in him" (verse 11). Her initiative played a multiple role, the creating of a new community of faith and the revealing of Jesus' glory and, at Cana, the solving of a threatening crisis in the wedding.

indeterminacy 'implies' the reader and begs her participation in synthesizing, and indeed living events of meaning throughout the process of reading" (http://prelectur.stanford.edu/lecturers/iser/) accessed 25/06/2013. 


\section{Women's Potentialities in Solving Crises}

\section{Awareness of the problem}

In the Cana story, the mother of Jesus was aware of the problem long before those who were supposed to be in charge, namely, the bridegroom and the master of the feast. This is in keeping with the daily experience of (Rwandan) women that confirms their ability to gain access to information, especially in the home, and to share it. Jesus' mother learned about the crisis before it could cause any damage. She understood what the consequences of the crisis would be and without informing even the master of ceremonies, she initiated its solution.

Her role in this story is mainly preventing a crisis from developing into an open cause for shame and feuding between the newly connected families. While at the wedding feast in Cana the crisis is no more than a local and very human story of potential disaster, its implications run deeper. The Cana story creates the possibility of a new awareness for Rwandans after the genocide, about women's ability to intervene in the peace-making process and to bring harmony to their communities if they take the opportunity. In fact, for any crisis to be solved it needs first to be identified. The capacity to be aware of the problem at an early stage helps to deal with it before it causes a great deal of damage. The mother of Jesus displayed that capacity and saved the Cana wedding hosts from public shame. But the awareness of the problem goes hand in hand with other qualities in solving crises.

\section{Women's Influence as a Tool for Conflict Resolution and its Limitations}

Besides the awareness of the problem beforehand, the mother of Jesus displayed some influence as a mother over him. While our analysis of the narrative has pointed to Jesus' rejection of a request based solely on kinship, his mother's continuing role is affirmed by his words to her and the Beloved Disciple at the cross (19:25-27). Jesus does not negate altogether the importance of family and kinship influence, though it is subject to the overriding needs of the new human community he establishes at the cross, where his mother and the Beloved Disciple, symbolic of the new community, are entrusted to each other. The power of women's influence over men around them is still a reality today. Women may be seen to be physically less strong than men in some patriarchal societies and cultures, sometimes they do not even hold positions of power, but they still have the ability to influence the decisions of men around them and to begin to exercise their own autonomous agency. At Cana Jesus rebuked the influence based solely on mother relationship, or blood ties, but his mother accepted the rebuke of her son in silence as she was determined to bring about change at the Cana wedding.

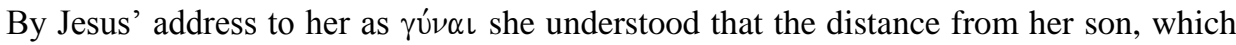
he insisted on, suggested a different approach which is beyond the mother-son relationship. In other words, she reacted as if she understood the narrowness of a blood tie relationship which could reach only a limited number of people. Instead, her relationship with Jesus in the narrative moves to a new and deeper level than simple family ties, the relationship of an autonomous woman moved to faith in Jesus as the one who responds to and supplies human need for its own sake. It is on these grounds that she was able to extend her influence to the servants. Her tact and willingness to listen enabled her to halt the crisis before it could degenerate into an irredeemable situation of shame. Jesus' mother's strategy can be an inspiration for the prevention of a crisis if emulated by women in other contexts of conflict. 


\section{Inspiration for Rwandan Women}

The situation of having no wine at the wedding, despite the likely consequences of shame and possibly feuding, may seem as not having much gravity. However, its consequences might have carried a considerable weight in the context of that wedding, hence becoming the root for conflict for the new couple and their families. The prevention of such consequences then is inspiring in the Rwandan context. The roots of the Rwandan conflict, the tragedy of the genocide and the consequences of women's failing to act on their precognition or awareness of a simmering problem are, of course, enormously out of proportion to the story of Jesus' mother's noticing a problem at a wedding. However, having acknowledged this, it is possible to compare the strategies used by Jesus' mother, their effectiveness and their transferability, with actions Rwandan women or others might take in averting a crisis.

Given their cultural role as peace-makers, Rwandan women could have been expected to display that ability before the genocide. But multiple obstacles, some of them based especially on the patriarchally biased politics of the country, did not allow women's involvement in policy or leadership. Discrimination based on gender was one of the major handicaps for women's access to the kind of information and influence which may have enabled them to play a peace-making role and helping to avert the crisis. The number of women who would have access to such information was meagre. The only woman who was in a position to access the information, the Prime Minister Mrs Uwiringiyimana Agate, and who tried to take action to avert the crisis, was assassinated as a way of silencing her at the very beginning of the genocide.

The lack of education for women in the Rwandan patriarchal society is among the reasons for the absence of their voices in the political issues of the country. Prior to the genocide women were trained in some sectors, but not to the extent of being part of the governance of the country. Traditionally young girls were to stay at home and assist their mothers. The priority in terms of education was given to boys who were the "potential leaders' (Mukangiliye 1980:70). Female education came in very late and even then was too elementary to open doors for women into leadership positions. Waller confirms, "In the area of government and administration, there were no women ministers until the coalition government of 1992. Nor were there any women prefects or burgomasters (communal administrators)..." (Waller 1996:56). Thus, it was very hard or even impossible for women to have information about the problematic Rwandan situation beforehand. The sad position for the majority of Rwandan women then was that they were rural peasants whose education and analytical capacity did not then and very often does not now reach such a level of awareness.

However, in the current situation after the genocide, women's increasing awareness of information can still be of help to the country. Most of the Rwandan population are wounded in one way or the other. Some are survivors of the genocide without any members of their family left. Others are left alone, as the members of their families are jailed or have died in jails or are still in custody because of true or false allegations of being involved in the genocide. All these different types of people live together in the same villages and communities with unresolved conflict. Social relationships are marred by mistrust as such groups hold bitterness in their hearts as a result of the genocide, a bitterness which can break out in new acts of violence and betrayal if not addressed. These few observations may help one to understand the kind of atmosphere in the country, especially in the rural areas. It is in this situation that Rwandan women might be called to play the role of 
reconciliation, each one at her level. Awareness of problematic situations may exist but for such awareness to bear the right fruit, the example of the mother of Jesus and her tactics in her interaction with Jesus could provide a model which could carry weight in a strongly Christian society such as Rwanda. ${ }^{11}$

\section{Women's Influence on Men, the Interaction with Jesus' Mother}

Women's influence is another ability pointed out by the above biblical analysis. Women can exert a powerful influence on men, especially those accessible to them, their sons and husbands. In the story of the wedding at Cana, it appears that Jesus' mother tried to influence her son on the basis of her family position. But this is not enough in and of itself. As Kruse argues, the mother's request seems to be motivated by the blood relationship and/or parental authority (Kruse 2003:92). The same influence based on kinship was observed in Rwanda especially within the royal settings of the Rwandan monarchy.

\section{Women's Influence on Men in the Rwandan Traditional Society}

Traditionally Rwandan women, commoners or royal, could influence the decision-making of their men, specifically their sons and husbands. This power was exhibited mainly by queen-mothers who ruled conjointly with their sons. In Rwandan history, the kind of approach attempted by Jesus' mother, approaching Jesus solely as a mother, could allow queen-mothers and other close relatives to wield considerable influence over the kings, to the extent of dictating to the monarchs. This influence could be constructive, of course, but some women displayed selfish and destructive motives, such as one renowned queenmother whose influence ended in the notorious coup d'état in which her step-son was assassinated together with many other people. Her influence on her brothers motivated the conspiracy to eliminate the legal king and enthrone her biological son (Taylor 1999:179). However, while many other queen-mothers exercised a constructive influence in the ruling of the country, it is clear that such a blood kinship-based influence re-enforces male patriarchy and cannot move beyond sectional kinship interests. This study seeks to move beyond this to shed light on the possibility of the influence of Rwandan women on men on the basis of their own autonomous faith and action, drawing inspiration from the action of the mother of Jesus at Cana.

\section{Rwandan women's Influence in the Light of Jesus' Mother's Example}

Culturally Rwandan women have opportunities to express their influence on men to the extent of changing their decisions. In Rwandan culture, a mother or a wife could stop her son or husband from being involved in a conflict by the cultural act of placing the traditional belt inside the gate (Bigirumwami 1984:43). If she would do such an act, the husband or the son could not cross over that belt to go out; if he ignored that act and went out eventually 'he would die'. Moreover, a man who would ignore such an act of his mother or wife was rejected by the community, which was a serious issue in the Rwandan society.

\footnotetext{
11 The failure of Christians and the Church(es) to halt the genocide remains a part of the legacy of guilt left by the genocide and continues to challenge Christians in Rwanda today to explore new avenues of faith and witness.
} 
However, such an influence, despite its effectiveness, was limited only to the family members. As pointed out above, even Jesus' mother was discouraged from exercising such an approach by her son because of its limitations. Hence, due to the range and seriousness of the problem of the Rwandan social conflict, this influence would not be effective even if women would try to exercise it, since it would only strengthen existing kinship divisions and become self-defeating. The limitations of this approach then suggest the adoption of an approach which could embrace a wider community. As the text revealed, when Jesus' mother accepted the challenge to connect with Jesus by faith beyond the dictates of culturally determined gender roles, her influence was able to reach even the servants who were not her kin. Later on, at his death, Jesus confirmed that inclusive approach at the cross when he entrusted his mother to the community of faith represented by the Beloved Disciple and not to his kin brothers. Moreover, he also entrusted the Beloved Disciple to the care of his mother in a relationship of mutual trust and acceptance (John 19:26-27).

Hence, at the cross Jesus' act placed Jesus' mother and the Beloved Disciple on an equal footing; they play equal roles in the new community which is bound by faith, not by blood or gender. By this act, Jesus seems to emphasize equality of men and women in their responsibilities in the community of faith. The approach, which embraces a widening community from the Cana wedding to the cross, resulted in the creation of a new community free of divisions based on biological ties, gender, and regional obligation.

Considering the situation in the Rwandan community, this article calls for such an inclusive approach which sets aside the primacy of the exercise of power based on one's own's family, clan or ethnic group. Such an approach which transcends human divisions needs to be based on a common faith in something greater than family, a transformative faith as those born 'from above' or 'over again' to become 'children of God', born not on the basis "of blood or of the will of the flesh or on the will of man, but of God" (John $1: 12,13)$. From John's point of view the community of faith is made of believers who are children of God because of faith and not because of natural descent. This community of faith embraces different people from different ethnic groups and regions, even traditional enemies. Cultural expectations of a woman's peace-making role in the family are important but not enough to address the Rwandan situation of conflict.

The analysis of the text then suggests to Rwandan women (and men) action mirroring Jesus' mother's attitude, of accepting the rebuke for their failure to make peace because of the influence of blood and kinship, and change of approach. As John points out this also involves the initiative of believing in God as a key for transformation, which may lead to the creation of a broader and more inclusive community(ies) of faith in the Rwandan community. From this understanding, the influence of women could be inclusive and involve solidarity with those beyond their kin and regions and going beyond gender stereotypes. By adopting such an approach, women and other members of the community could address effectively the tensions resulting from the genocide and other civil conflicts in the community. The role of Jesus' mother at Cana then challenges Rwandan (men and women) Christians to go beyond their gender, local influence, local interests and find new and more effective ways of bringing harmony into their communities. 


\section{BIBLIOGRAPHY}

Bechtel, Lyn M 1996. A symbolic level of meaning: John 2:1-11, in Brenner, Athalya. (ed.). The feminist companion to the Hebrew Bible in the New Testament, 241-256. Sheffield: Sheffield Academic Press.

Bigirumwami, Aloyis 1984. Imihango n'imizililizo mu Rwanda (Rites pratiques et interdis au Rwanda. Nyundo, Rwanda: Secretariat du Diocese Nyundo.

Brodie, Thomas 1993. The Gospel according to John: A literary and theological commentary. New York: Oxford University Press.

Brown, Raymond E 1984. The Gospel according to John Vol.1. London: Geoffrey Chapman.

Dube, Musa (ed.). 2003. Grant me Justice: Towards Gender-Sensitive Multi-sectoral HIV/AIDS Readings of the Bible. In Grant me Justice! HIV/AIDS \& Gender Readings of the Bible). Pietermaritzburg: Cluster Publication.

Francis, Diana 2004. Rethinking war and peace. London: Pluto.

Feuillet, A 1986. Les épousailles du Messie: La Mère de Jésus dans le Quatrième Evangile. Revue Thomiste 83(3):357-391.

Hanson, Kenneth C and Oakman, Douglas 1998. Palestine in the time of Jesus: Social structures and social conflicts. Minneapolis, Minnesota: Fortress.

Howard-Brook, W 1994. Becoming children of God. Maryknoll, New York: Orbis.

Keener, Craig S 2003. The Gospel of John V1. Peabody, Mass: Hendrickson.

Köstenburger, J Andreas 2004. John. Grand Rapids, Michigan: Baker.

Kruse, Collin G 2003. The gospel according to John: An introduction and commentary. Leicester: InterVarsity Press.

Lederach, John Paul 1995. Preparing for peace: Conflict transformation across cultures. Syracuse, New York: Syracuse University Press.

Lee, Dorothy 1994. The symbolic narratives of the Fourth Gospel: The interplay of form and meaning. Sheffield, England: JSOT Press.

Malbon, Elisabeth S 2000. In the company of Jesus: Characters in Mark's Gospel. Louisville, Kentucky: Westminster John Knox.

Malina, Bruce 1998. Social science commentary on the Gospel of John. Minneapolis, Minnesota: Fortress.

Mukangiliye, Colette 1980. Les missions Protestants Belges au Rwanda 1921-1961. [Université Libre de Bruxelles Faculté des sciences sociales, politiques et économiques]. Bruxelles: Tervuuren.

Myre, Andre 2000. The New Testament in Women's Commentary. In Caron, Gerald (ed.). Women Also Journeyed with Him: Feminist Perspective on the Bible (83-98).

Collegeville: The Liturgical Press.

Neyrey, Jerome H 2007. The Gospel of John. Cambridge: Cambridge University Press.

Nortje-Meyer, Lilly 2009. The 'Mother of Jesus' as analytical category in John's Gospel. Neotestamentica 43 (1), 123-143. 
Nyirimana, Eraste 2010. The tribal dimension in the division of the kingdom of Israel: A contextual study of Kings 12:1-24 from the perspective of the struggle for national unity in Rwanda. Unpublished PhD Thesis. University of KwaZulu-Natal, Pietermaritzburg.

Reinhartz, Adele 1999. God the Father in the Gospel of John. Atlanta: Society of Biblical Literature.

Ridderbos, Herman 1997. The Gospel according to John: A theological commentary. Grand Rapids, Michigan: Williams B Eerdmans.

"Stone water jars at Capernaum".

http://dqhall59.com/israelphotosIV/stonewaterjars.htm.http:// (accessed 25/06/2013).

Suggit, John 1993. The Sign of life: Studies in the Fourth Gospel and the liturgy of the church. South Africa, Cape Town: Galvin \& Sales.

Taylor, Christopher C 1999. Sacrifice as terror: The Rwandan genocide of 1994. New York: Berg.

Ukpong. S Justin 1995. "The parable of the shrewd manager (Luke 16:1-13). An Essay in Inculturation Biblical Hermeneutics" Semeia. 73:189-210.

Van Aarde, Andries 2001. Fatherless in Galilee: Jesus as child of God. Harrisburg: Trinity Press International.

Vlassenroot, Koen 2006. A societal view on violence and war: Conflict \& militia formation in Eastern Congo, in Kaarsholm, Preben (ed.). Violence, political culture \& development in Africa, 49-65. Pietermaritzburg: University of KwaZulu-Natal Press.

Waetjen, Herman 2005. The gospel of the beloved disciple: A work in two editions. New York: T\&T Clark.

Waller, David 1996. Rwanda: Which way now? United Kingdom: Oxfam Print Unit.

West, Gerald O 2009. Interpreting 'The Exile' in African Biblical Scholarship:

An Ideo-Theological Dilemma in Post-Colonial South Africa. Pages 247-267 in

Exile and Suffering: A Selection of Papers Read at the $50^{\text {th }}$ Anniversary Meeting of the Old Testament Society of South Africa OTWSA/OTSSA, Pretoria August 2007. Edited by Bob Becking and Dirk Human. Leiden/Boston: Brill.

Whitacre, Rodney A 1999. John. Illinois: InterVarsity.

Witherington III, Ben 1990. Women and the genesis of Christianity. Cambridge:

Cambridge University Press. 